\title{
Pharmacognostical and Phytochemical Analysis of Ayurveda Medicine (Atibala) Abutilon indicum (Linn.) Sweet Roots Collected From Field
}

\author{
${ }^{1}$ Dr. Sukha ram*, ${ }^{2}$ Dr. Amit Choudhary, ${ }^{3}$ Prof. Mita Kotecha, \\ ${ }^{4}$ Dr. Krutika Chaudhary, ${ }^{5}$ Dr. Sunita Dudi \\ ${ }^{1,2}$ P.G. Scholar, P.G. Department of Dravyaguna Vigyana, \\ ${ }^{3}$ Professor and H.O.D., P.G. Department of Dravyaguna Vigyana, \\ ${ }^{4}$ Lecturer, P.G. Department of Dravyaguna Vigyana, \\ ${ }^{5}$ P.G. Scholar, P.G. Department of Sharir Rachana, \\ National Institute of Ayurveda, Jaipur
}

\begin{abstract}
Atibala (Abutilon indicum Linn.) Sweet belonging to Family Malvaceae is very important plant since long in traditional medicine of India and grows in waste places. The drug is attributed Balya Kantivardhaka, Grahi, Ojovardhaka, Brinhana, Krimighna, Dahahara, Vatahara, Rasayana, Mutrajanana, Mridurechana, Vajikara, Kasahara and Vedanahara properties in different Ayurvedic classical texts. Pharmacognostical and phytochemical studies are essential for proper identification and authentication of the drug. Various methods including microscopy, physiochemical contents and phytochemical estimation along with quantitative analysis were conducted to evaluate Pharmacognostical, physiochemical and preliminary phytochemical standards of Atibala (Abutilon indicum (Linn.) Sweet roots. These studies can be helpful to define diagnostic features for identification and standardization of both intact and powdered drug. The organoleptic examination of the intact and powdered materials of roots of Atibala revealed light brown color, odourless odour and astringent and bitter taste. After analysing result of present study, we found presence of carbohydrates, tannins, protein, alkaloid, saponin, amino acids and phenolic compounds in both alcoholic and aqueous extract. Present study will be helpful in ensuring efficacy of the drug, safety, purity and about adulteration of drug.
\end{abstract}

Keywords:- Atibala, Abutilon indicum (Linn.) Sweet, Kantikaraka, Rasayana and Pharmacognostical

\section{INTRODUCTION}

Abutilon indicum (Linn.) Sweet (Malvaceae) is widely distributed throughout India up to $1200 \mathrm{~m}$ in Sub Himalayan tracts and also in Srilanka. Abutilon indicum (Linn.) Sweet is a perennial shrub, softly tomentose and up to $3 \mathrm{~m}$ in height. ${ }^{1}$ The drug is used as ethano - medicine by tribal of India for anthelmintic, antiemetic, antiinflammatory, in urinary or uterine discharge, piles, fever, dry cough, bronchitis, gonorrhoea and leprosy in different Ayurveda classical texts. Atibala is reported as having Madhura Rasa, Laghu - Snigdha - Pichchhila Guna, Shita Virya, Madhura Vipaka and Vatapittahara Karma etc. and attributed Balya, Kantivardhaka, Grahi, Ojovardhaka,
Brinhana, Krimighna, Dahahara, Vatahara, Rasayana, Mutrajanana, Snehana, Mridurechana, Vajikara, Kasahara and Vedanahara properties. The historical evidence of Atibala is traced from Vedic period, Samhita period ancient Nighantu period to current modern texts. After medieval period, various types of Atibala are described by Samhitas and Nighantus under title of Baladvaya, ${ }^{2},{ }^{3}$ Balatraya, ${ }^{4}$ Balachatushtay $a^{5}$ and Balapanchaya ${ }^{6}$. Classically, there are varieties of 2 type's namely small and big types. The small variety corresponds to Abutilon indicum (Linn.) Sweet whiles the large variety to Abutilon hirtum (G. Don.). ${ }^{7}$ Also, various drugs are added as adulteration and substitute in market samples of Atibala. Hence, authentication of the Abutilon indicum (Linn.) Sweet on macroscopic and microscopic level is the need of hour. This, study is aimed for the same.

\section{MATERIALS AND METHODS:}

Microscopic, physiochemical and phytochemical studies including quantitative analysis of Abutilon indicum (Linn.) Sweet was carried out to determine diagnostic features of drug, identification and standardization for both intact and powdered drug. All the standard references of procedures were followed from authentic books and sources during the study.

\section{$>$ Collection of sample:}

Atibala plants were collected following standard collection method from Jaipur district, Rajasthan state. The authentication of used plant parts was carried out at botany department, University of Rajasthan, Jaipur vide reference number RUBL211727 as Abutilon indicum (Linn.) Sweet and belong to family Malvaceae. After authentic identification of plant, roots of Atibala was washed and processed by proper method. Procured parts of drug were powdered, labelled and packed for further study.

Taxonomic classification of Atibala ${ }^{8}$.

Kingdom - Plantae

Subkingdom - Tracheobionta

Superdivision - Spermatophyta

Division - Magnoliophyta

Class - Magnoliopsida

Subclass - Dilleniidae 
Order - Malvales

Family - Malvaceae

Genus - Abutilon Mill.

Species - Abutilon indicum (Linn.) Sweet

\section{$>$ Place of Work:}

The microscopic, physiochemical, phytochemical and TLC studies of the drug was carried out in the P.G. Department of Dravyaguna Vigyana Laboratory of National Institute of Ayurveda, Jaipur.

\section{$>$ Procedure:}

The present study of the plant Atibala - Abutilon indicum (Linn.) Sweet is performed in some sections namely: Analysis of Pharmacognostical studies, Physiochemical parameters studies, Preliminary phytochemical studies and Thin Layer Chromatography (T.L.C.).

\section{$>$ Pharmacognostical study:}

Pharmacognostical study was completed by using color, odour and taste etc. like morphological characters.

\section{$>$ Physiochemical study:}

Moisture Content: ${ }^{9}$ For determining moisture content in sample, placed and weighed sample of $5 \mathrm{~g}$ in hot oven at $105^{\circ}$ temperature for five hours and calculated weight of sample in every 30 minutes until weight of sample becomes constant with no variation. Sample was placed at room temperature in a dissector for 1 hour before weighing.

\section{$>$ pH value: $:^{10}$}

$\mathrm{pH}$ value practically indicates acidic or basic nature of an aqueous solution, which is defined by using common reciprocal of $\mathrm{H}^{+}$ions concentration expressed in gram per liter.

The $\mathrm{pH}$ of a given solution is measured by using digital $\mathrm{pH}$ meter. First Standardized the $\mathrm{pH}$ meter. Tablets of different $\mathrm{pH}$ were taken and each tablet was dissolved in $100 \mathrm{ml}$ of distilled water to prepare solutions of different $\mathrm{pH}$. The instrument was switched on and left for some time until required different $\mathrm{pH}$ solutions appeared. Buffer solution was taken in the beaker and the electrode was dipped in it. Same procedure was repeated for the other buffer solution after washing the electrode thoroughly with distilled water. The sample was taken (10\% aqueous solution) and electrode was dipped in it and the value of $\mathrm{pH}$ was noted.

\section{Extractive values: ${ }^{11}$}

Alcohol Soluble Extractive: - $5 \mathrm{~g}$ coarsely powdered air dried drug was macerated with $100 \mathrm{ml}$ of alcohol of the specified strength in closed flask for twenty-four hours. Then it was continuously shaken for six hours using rotary shaker and allowed to stand for eighteen hours. The content was filtered using filter paper. The filtrate was transferred to a pre-weighed flat bottomed dish and evaporated to dryness on a water bath. Then, the dish was kept in oven at $105^{\circ}$, to constant weight and weigh. The percentage of alcohol-soluble extractive was calculated with reference to the air-dried drug.

Water Soluble Extractive: - $5 \mathrm{~g}$ coarsely powdered air dried drug was macerated with $100 \mathrm{ml}$ of water of the specified strength in a closed flask for twenty-four hours. Rotary shaker was used for shaking solution till 6 hours and placed on stand for 18 hours. Filter paper was used for filtering content. The filtrate was transferred to a preweighed flat bottomed dish and evaporated to dryness on a water bath. Then, the dish was placed in oven at temperature of $105^{\circ}$, to constant weight and weighed. The percentage of water-soluble extractive was calculated with context of air-dried drug.

$$
\text { Ash value: }{ }^{12}
$$

Total Ash: - For calculation of total ash value in the sample, $2 \mathrm{~g}$ of the drug was weighed in silica dish and burned at $450^{\circ}$ for carbon free sample. After this it was weighed again and calculated percentage of ash value in context of air dried drug.

Acid Insoluble Ash: - Boiled the total ash with $25 \mathrm{ml}$ of $2 \mathrm{M}$ hydrochloric acid for 5 minutes, collected the insoluble matter in Gooch crucible or an ash less filter paper, washed with hot water, ignite, cool in a desiccator and weighed. Calculate the percentage of acid insoluble ash with reference to the air dried drug.

Water Soluble Ash: - Boiled the total ash for 5 minutes with $25 \mathrm{ml}$ of water; collected the insoluble matter in a Gooch's Crucible or on an ash less filter paper, Washed with hot water and ignite for 15 minutes at a temperature not exceeding $450 \mathrm{C}$. Subtract the weight of the insoluble matter from the weight of the ash; the difference in weight represented the water - soluble ash. Calculate the percentage of water soluble ash with reference to the air - dried drug.

- Phytochemical Analysis:

Phytochemical examinations were performed according to standard methods.

\section{Carbohydrates:}

Molisch's Test: - Equal quantity of test Solution and Molisch's reagent was added and shaken carefully and then about $1 \mathrm{ml}$. of concentrated $\mathrm{H}_{2} \mathrm{SO}_{4}$ is poured from side of the test tube and allowed to stand for one 1 minute. Forming a purple color ring at the junction of the two layers indicates presence of carbohydrate.

Benedict's test: - It is used for reducing sugars and composed of mainly copper sulphate and sodium hydroxide. To the $4 \mathrm{ml}$ of aqueous solution of drug, $1 \mathrm{ml}$ of Benedict's solution was added and heated almost to boiling. Solution appears green, yellow, orange, red or brown colour in order of increasing concentrations of simple sugar in the test solution. 
Fehling solution test: - This test is generally used for reducing sugars and composed of two solutions, which are mixed in situ. Fehling solution A composed of $0.5 \%$ of copper sulphate whereas Fehling solution B composed of Sodium Potassium Tartarate. Equal volumes of Fehling A and Fehling B solutions were mixed $(1 \mathrm{ml}$ each) and $2 \mathrm{ml}$ of aqueous solution of drug was added followed by boiling for 5-10 minutes on water bath. Formation of reddish brown colored precipitate due to formation of cuprous oxide indicates presence of reducing sugar.

\section{Alkaloids:}

Dragondroff's reagent test: - $2 \mathrm{ml}$ of test solution was mixed with $2 \mathrm{ml}$ of the Dragondroff's reagent. Forming an orange precipitate indicated presence of alkaloids.

Wagner's Test: - Test solution was mixed with few drops of Wagner's reagent (Dilute Iodine solution) in test tube; formation of reddish brown precipitate shows presence of alkaloids.

Hager's Test: - A saturated aqueous solution of picric acid was employed with test filtrate. An orange yellow precipitate was obtained which indicates the presence of alkaloids.

\section{Amino acids:}

Ninhydrin test: - This test is used for detection presence of alpha-amino acids and proteins containing free amino groups. Protein solution when heated with ninhydrin molecules, it gives characteristic deep blue or pale yellow color due to deformation of complex between two ninhydrin molecules and nitrogen of free amino acid.

\section{Proteins:}

Biuret test: - A few $\mathrm{mg}$ of the residue was taken in water and $1 \mathrm{ml}$ of $4 \%$ sodium hydroxide solution was added to it, followed by a drop of $1 \%$ solution of copper sulphate. Development of violet or pink color indicates the presence of proteins.

Xanthoprotic test: - For this test sample was taken with $2 \mathrm{ml}$ of water and $0.5 \mathrm{ml}$ of concentrated nitric acid was added. Formation of yellow color indicated presence of protein.

Millon's test: - A small quantity of test sample was taken and 2 to $3 \mathrm{ml}$ of millon's reagent was added. The white precipitate slowly turning to pink, indicate the presence of proteins.

\section{Saponin:}

Foam test: - A small quantity of the test sample was taken in a test tube and shaken vigorously with a small amount of sodium bicarbonate and water. A stable, characteristic honeycomb like froth indicates the presence of saponin.

\section{Glycosides:}

Borntragor's test: - $1 \mathrm{ml}$ of Benzene and $0.5 \mathrm{ml}$ of dilute ammonia solution was added to the extract and was observed for the formation of reddish pink color.

Phenolic Compound: - The extract was taken in water and heated then $2 \mathrm{ml}$ ferric chloride solution was added and observed for the formation of green and blue color.

\section{Steroids:}

Salkoweski reaction: - A little amount of extract was taken in test tube and mixed with chloroform and sulfuric acid each $2 \mathrm{ml}$. After that, test tube was shaken for few minutes. Forming of red color in sample indicates presence of steroids.

\section{Tannins:}

Ferric chloride solution: - Ferric chloride solution was prepared by using $90 \%$ alcohol for $5 \%$ solution. 2-3 drops were added to filtrate and appearance of dark green or deep blue color indicated presence of tannins.

Lead acetate: - $10 \% \mathrm{w} / \mathrm{v}$ solution of basic lead acetate in distilled water was added to the test filtrate. Formation of precipitate showed presence of tannins.

Potassium Dichromate: - To check presence of tannins in sample potassium dichromate solution was added to the filtrate. Appearance of dark color indicates presence of tannins.

\section{Thin Layer Chromatography (TLC): -}

TLC is used for identification and separation of chemical constituents. TLC is a technique in which a solute undergoes distribution between two phases, stationary phase acting through adsorption and mobile phase in the form of a liquid. The adsorbent is a relatively thin, uniform layer of dry finely powdered material applied to a glass, plastic or metal sheet or plate. Glass plates are commonly used. Separation may also be achieved on the basis of partition or a combination of partition and adsorption, depending on the particular type of support, its preparation and its use with different solvent.

Identification can be effected by observation of spots of identical $R_{f}$ value and about equal magnitude obtained, respectively, with an unknown and a reference sample chromatographed on the same plate. A visual comparison of the size and intensity of the spots usually serves for semi-quantitative estimation. 
Chromatography plates: - Chromatography plate coated with $0.25 \mathrm{~mm}$ layer of silica gel $60 \mathrm{~F}_{254}$ with fluorescent indicator was used. (Dimensions of each plate is $10 \mathrm{~cm}$ long and $2 \mathrm{~cm}$ width)

Activation of pre coated silica gel 60 F254: - For this, plates were dried in oven at $105^{0} \mathrm{C}$ for 90 minutes.

Preparation of mobile solution: - $\mathrm{n}$ - Butanol : Acetone : Acetic acid : Water (30:30:10:20)

Preparation of test solution: - $4 \mathrm{~g}$ powdered drugs were extracted with $100 \mathrm{ml}$ of ethanol (90\%) in Soxhlet's apparatus consecutively three times. Extract was filtered and concentrated to $10 \mathrm{ml}$.

Sample application: - Sample was applied $1 \mathrm{~cm}$ above from the base of T.L.C. plate by the help of capillary and removed when spot reached $1 \mathrm{~cm}$ below the top of T.L.C. plate from mobile solution.

Visualization: - Iodine Vapors.

$\mathbf{R}_{\mathbf{f}}$ Value: - For $R_{\mathrm{f}}$ value we measured the distance travelled by each spot from its application point and divided it by distance travelled by the front of the mobile phase.

\section{$>$ Observations and Results:}

The different Pharmacognostical parameters were studied and evaluated in order to standardize the drug. The results of Pharmacognostical parameters i.e. microscopic study, physicochemical parameters, phytochemical analysis and T.L.C. have been cited in below.

- Macroscopic study of Abutilon indicum (Linn.) Sweet root powder: -

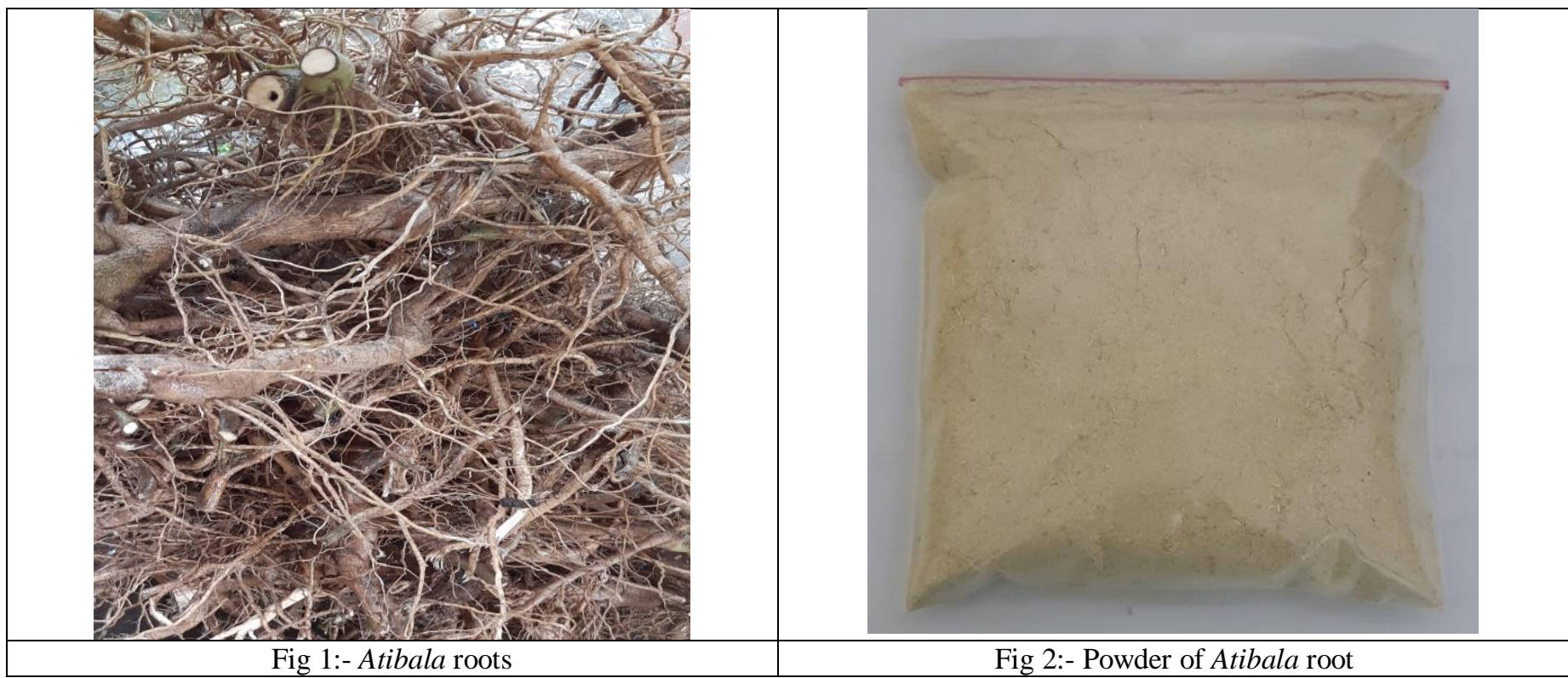

\begin{tabular}{|c|c|c|}
\hline S. No. & Observed & Abutilon indicum (Linn.) Sweet \\
\hline 1. & Color & Light brown \\
\hline 2. & Odour & Odourless \\
\hline 3. & Taste & Astringent and bitter \\
\hline
\end{tabular}

Table 1:- Macroscopic examination of Abutilon indicum (Linn.) Sweet root powder

- Powder microscopic study of Abutilon indicum (Linn.) Sweet root: -

In powder microscopy, structure like Fiber, Calcium Oxalate crystals and Starch grains, Cork cells were seen.

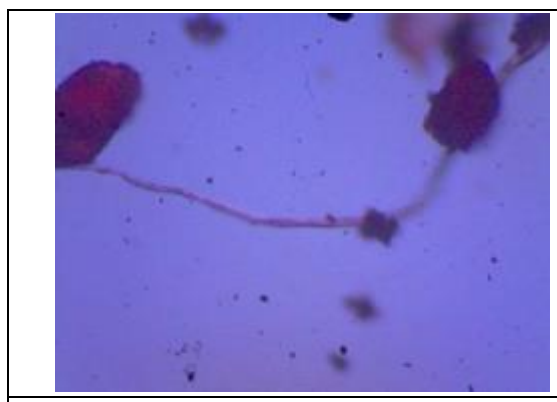

Fiber

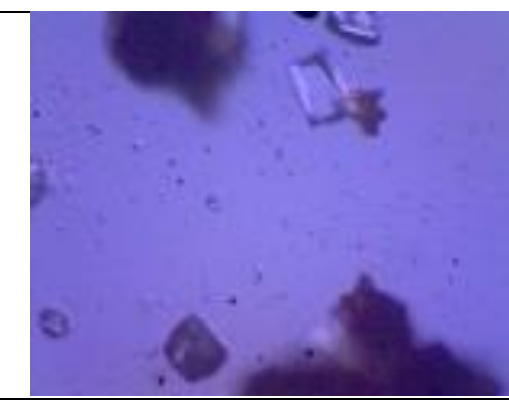

Calcium Oxalate and Starch Grain

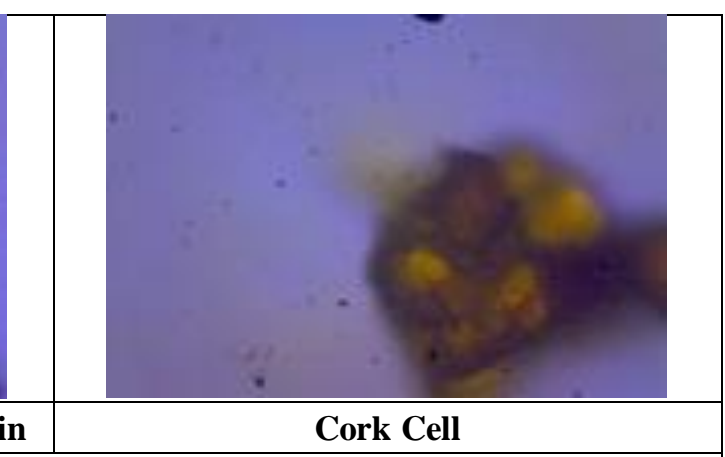

Cork Cell

Fig 3:- Powder microscopic characteristic of Atibala root. 
- Physiochemical parameters: -

In present study moisture content, $\mathrm{pH}$, extractive value (alcohol soluble extractive value and water soluble extractive value) and ash values (total ash, acid insoluble ash and water soluble ash) were determined below in Table 2.

\begin{tabular}{|c|c|c|c|}
\hline S. No. & Physiochemical parameter & Results \% w/w & API standard value \\
\hline 1. & Moisture content & $4.45 \%$ & NMT6.5\% \\
\hline 2. & $\mathrm{pH}$ value & 5.5 & -- \\
\hline 3. & Water soluble extractive value & $12.19 \%$ & NLT $9 \%$ \\
\hline 4. & Alcohol soluble extractive value & $3.5 \%$ & NLT $3 \%$ \\
\hline 5. & Total ash & $7.54 \%$ & NMT $8 \%$ \\
\hline 6. & Acid insoluble ash & $2.56 \%$ & NMT 3\% \\
\hline 7. & Water insoluble ash & $5.67 \%$ & Not mention \\
\hline
\end{tabular}

Table 2:- Physiochemical analysis of Abutilon indicum (Linn.) Sweet roots powder

\section{- Phytochemical analysis:}

Phytochemicals are produced by plants through primary and secondary metabolism. First one is directly associated with plant growth (carbohydrate, protein and lipids) while secondary metabolites (alkaloids, glycosides, flavonoids and saponins) acts as defence system of plant. The introductory phytochemical studies of alcoholic and aqueous extract of Abutilon indicum (Linn.) Sweet roots were performed which showed the presence of carbohydrate, proteins, phenolic compound, steroids and tannins etc. The outcomes are mentioned in Table 3.

\begin{tabular}{|c|c|c|}
\hline \multirow[t]{2}{*}{ Name of Test } & \multicolumn{2}{|c|}{ Abutilon indicum (Linn.) Sweet } \\
\hline & Aqueous & Alcoholic \\
\hline \multicolumn{3}{|c|}{$(+$ ve $)=$ Positive and $(-$ ve $)=$ Negative } \\
\hline \multicolumn{3}{|c|}{ Carbohydrate Tests } \\
\hline Molish Test & $+\mathrm{ve}$ & $+\mathrm{ve}$ \\
\hline Benedict test & $+\mathrm{ve}$ & $+\mathrm{ve}$ \\
\hline Fehling test & + ve & + ve \\
\hline \multicolumn{3}{|c|}{ Alkaloids Tests } \\
\hline Dragondorff Test & - ve & $+\mathrm{ve}$ \\
\hline Wagner's Test & - ve & - ve \\
\hline Hager's Test & $+\mathrm{ve}$ & - ve \\
\hline \multicolumn{3}{|c|}{ Amino Acids Test } \\
\hline Ninhydrine Test & $+\mathrm{ve}$ & - ve \\
\hline \multicolumn{3}{|c|}{ Proteins Test } \\
\hline Biuret Test & $+\mathrm{ve}$ & - ve \\
\hline Xenthoprotic Test & $+\mathrm{ve}$ & + ve \\
\hline Millon's Test & - ve & - ve \\
\hline \multicolumn{3}{|c|}{ Saponine Test } \\
\hline Foam Test & + ve & - ve \\
\hline \multicolumn{3}{|c|}{ Glycosides Test } \\
\hline Borntragor's Test & - ve & - ve \\
\hline \multicolumn{3}{|c|}{ Phenolic compound Test } \\
\hline Phenolic Test & $+\mathrm{ve}$ & $+\mathrm{ve}$ \\
\hline \multicolumn{3}{|c|}{ Steroids Test } \\
\hline Salkowaski reaction & - ve & - ve \\
\hline \multicolumn{3}{|c|}{ Tannins Test } \\
\hline $\mathrm{FeCl}_{3}$ Test & + ve & $+\mathrm{ve}$ \\
\hline Lead acetate Test & $+\mathrm{ve}$ & $+\mathrm{ve}$ \\
\hline Pot. Dichromate Test & - ve & + ve \\
\hline
\end{tabular}

Table 3:- Phytochemical analysis of Abutilon indicum (Linn.) Sweet root powder 


\begin{tabular}{|c|c|}
\hline Sample & Abutilon indicum (Linn.) Sweet \\
\hline $\mathbf{R}_{\mathbf{f}}$ velue & $0.39,0.70,0.82,0.88,0.92,0.98$ \\
\hline
\end{tabular}

Table 4:- Thin Layer Chromatography of Abutilon indicum (Linn.) Sweet root powder

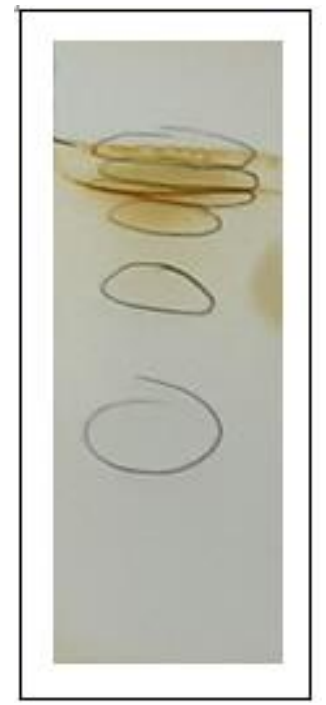

Fig 4:- Thin Layer Chromatography of Abutilon indicum (Linn.) Sweet root powder

\section{DISCUSSION}

Abutilon indicum (Linn.) Sweet is astringent and bitter in taste, odourless in odour and light brown in colour. Powder microscopic study of roots powder of Abutilon indicum (Linn.) Sweet revealed Fiber, Calcium Oxalate crystals and Starch grains, Cork cells after observation under microscope. Loss on drying is a water holding property of test substance. Moisture content and $\mathrm{pH}$ value was found to be $4.45 \%$ and 5.5. Extractive value is directly relative to strength or potency of drug which estimates in different solvents. Water soluble extract value was found in sample $12.19 \%$ and alcoholic extractive value was found $3.5 \%$. Ash value is the indicator of the presence of inorganic and earthy matter in the plant. The higher ash value is suggestive of thermo - non labile / heat stable or inorganic constituents. The total ash value in sample $7.54 \%$, the acid insoluble content which indicates the presence of siliceous matter and heavy metals in sample $2.56 \%$. Water soluble ash estimates the inorganic water soluble salt in sample $5.67 \%$. Qualitative analysis of inorganic matter showed presence of carbohydrate, tannin, proteins, amino acids, alkaloids, saponin and phenolic compounds, in Abutilon indicum (Linn.) Sweet root powder. Thin layer chromatography establishes the phytochemical fingerprint profiling in drug for identity.

\section{CONCLUSION}

Fiber, Calcium Oxalate crystals, Starch grains and Cork cells are the peculiar character of (Atibala) Abutilon indicum (Linn.) Sweet observed in microscopic study. The qualitative phytochemical screening of (Atibala) Abutilon indicum (Linn.) Sweet root sample revealed that carbohydrate, tannins, proteins, alkaloids, phenolic compounds, were present in both aqueous and alcoholic extracts, while amino acid and saponin were present only in aqueous extract. Various physiochemical parameters such as loss on drying value, $\mathrm{pH}$ value, water and alcohol soluble extract etc. were found within standard limit. Values received from above analysis may be useful in detecting adulteration of a sample. All studied standardization parameters provide understandings in identification and authentication of Abutilon indicum (Linn.) Sweet roots.

\section{REFERENCES}

[1]. P. C. Sharma, M. B. Yelne, T. J. Dennis etc. Database on Medicinal Plants used in Ayurveda, Vol. - 1, Central Council for Research in Ayurveda and Siddha, 2000

[2]. P. Kashinath pandey and Dr. Gorkhnath chturvedi, Charaka Samhita, viddhotini comentry, Varanasi, Chaukhamba Bharati Academy, reprint 2013

[3]. Dr. Sukha ram et al. Phyto - Pharmacognostic Analysis of Ayurvedic Medicine Bala (Sida Cordifolia Linn.) IRJAY, June: 2020, Vol- 3, Issue-6

[4]. Vagbhatt, Ashtanga Hridaya with Nirmala Hindi Commentary by Dr. Brahmanand Tripathi, Delhi, Chaukhamba Sanskrit Pratishthan, reprint 2017

[5]. Prof. K. C. Chunekar, Bhavprakash nighantu (indian meteria medika), Varanasi, Chaukhamba Bharati Academy, reprint 2015

[6]. Sharma P. V., Priya Nighantu, Varanasi, Chaukhamba Surbharti Prakashana, 2015

[7]. Chunekar KC, Bhavaprakash nighantu (Indian Materia Medica), Chaukhambha Bharti academy, 2015

[8]. https://plants.usda.gov/core/profile?symbol=ABIN3

[9]. Laboratory guide for the analysis of Ayurveda and siddha formulations, CCRAS, Dept. of Ayush, ministry of health and family welfare, govt. of India New Delhi 
[10]. Laboratory guide for the analysis of Ayurveda and siddha formulations, CCRAS, Dept. of Ayush, ministry of health and family welfare, govt. of India New Delhi

[11]. Laboratory guide for the analysis of Ayurveda and siddha formulations, CCRAS, Dept. of Ayush, ministry of health and family welfare, govt. of India New Delhi

[12]. Laboratory guide for the analysis of Ayurveda and siddha formulations, CCRAS, Dept. of Ayush, ministry of health and family welfare, govt. of India New Delhi 